\title{
The collapse of marine forests: drastic reduction in populations of the family Sargassaceae in Madeira Island (NE Atlantic)
}

\author{
Alejandro Bernal-Ibáñez ${ }^{1}$ (I) Ignacio Gestoso ${ }^{1,2} \cdot$ Peter Wirtz $^{3} \cdot$ Manfred Kaufmann $^{4,5} \cdot$ Ester A. Serrão $^{3}$. \\ João Canning-Clode ${ }^{1,2} \cdot$ Eva Cacabelos $^{1}$
}

Received: 23 December 2020 / Accepted: 6 June 2021 / Published online: 1 July 2021

(C) The Author(s) 2021

\begin{abstract}
Species of the genera Cystoseira, Ericaria, Gongolaria, and Sargassum (family Sargassaceae) are key components of the Mediterranean-Atlantic marine forests, essential for biodiversity and ecosystem functioning. Populations of these foundational species are particularly vulnerable to anthropogenic impacts, likely to be intensified under future scenarios of climate change. The decline and even disappearance of these species have been reported in different areas of the world. At Madeira Island (NE Atlantic), populations of Gongolaria abies-marina, Ericaria selaginoides, Sargassum vulgare, and Sargassum filipendula, the most ecologically relevant species in Macaronesian marine forests, have been suffering a drastic decline during the last decades, especially on the southern coast of the island, where anthropogenic pressure is higher than on the north coast. The lack of sufficient temporal coverage on qualitative and quantitative studies of Sargassaceae communities in Madeira poses a challenge to establish a specific period for this decline. Consulting qualitative studies and historical records, we have set for the first time a timeline that shows an evident decrease in Sargassaceae populations in the last 20 years on Madeira Island. Following this timeline, we pinpoint the start of this decline in the first decade of the 2000s. This can be particularly confirmed for places like Funchal and Reis Magos, with significantly higher historical records. Currently, most benthic communities on shallow subtidal rocky reefs along the south coast are dominated by sea urchins and crustose coralline algae, the so-called sea urchin barrens. However, in some cases, they are entirely covered by a layer of sediment. We discuss the possible factors contributing to these drastic changes, bringing Madeira's marine forests to a dramatic decline. As many animal species rely on marine forests, the decline of Sargassaceae populations represents an invaluable ecological loss for the coastal ecosystem of the island.
\end{abstract}

Keywords Marine forests $\cdot$ Anthropogenic pressures $\cdot$ Cystoseira $\cdot$ Ericaria $\cdot$ Gongolaria $\cdot$ Sargassum $\cdot$ Madeira $\cdot$ Macaronesia

\section{Introduction}

Communicated by Anne Bousquet-Melou

Alejandro Bernal-Ibáñez

alejandro.bernal@mare-centre.pt

1 MARE - Marine and Environmental Sciences Centre, Agência Regional para o Desenvolvimento da Investigação Tecnologia e Inovação (ARDITI), Madeira, Portugal

2 Smithsonian Environmental Research Center, Edgewater, USA

3 CCMAR - Center of Marine Sciences, CIMAR, University of Algarve, Campus de Gambelas, 8005-139 Faro, Portugal

4 Faculty of Life Sciences, Marine Biology Station of Funchal, University of Madeira, Madeira, Portugal

5 CIIMAR - Interdisciplinary Centre of Marine and Environmental Research, CIMAR, University of Porto, Matosinhos, Portugal
Macroalgal forests (order Laminariales Migula, 1909, and order Fucales Bory, 1827) represent one of the most productive habitats along temperate rocky coasts worldwide (Dayton 1985). These marine forests alter the physical, chemical, and biological conditions of the environment (Ballesteros 1992; Hoffmann et al. 1992; Ballesteros et al. 1998; Hirsh et al. 2020) with their high rates of primary productivity and by providing complex biogenic habitat, shelter, food, and nurseries for numerous species (Boudouresque 2004; Fraschetti et al. 2011; Giakoumi et al. 2012; Smale et al. 2013). Moreover, they are considered biological indicators of water and ecosystem quality (Gros 1978; Panayotidis et al. 1999; Pinedo et al. 2006).

Fucoids (Fucales, Ochrophyta) are "engineering species" (sensu Jones et al. 1997), present along rocky shores of 
temperate and subtropical areas. In pristine environments, these key species may become dominant (Schiel and Foster 2006), forming large canopies essential for biodiversity and ecosystem functioning (Bermejo et al. 2018 and references therein). The decline of fucoids (as well as kelp, mainly in the orders Laminariales and Tilopteridales, Ochrophyta) is a global tendency directly or indirectly induced by human activities (Wernberg et al. 2011; Franco et al. 2015). In recent decades, studies have detected the decline and even the disappearance of entire populations of the family Sargassaceae, across European waters, due to different human pressures, namely habitat destruction, overgrazing, sedimentation, invasive species, pollution, and ocean warming (Soltan et al. 2001; Airoldi 2003; Hill et al. 2003; Tuya et al. 2004; Clemente 2007; Roleda and Dethleff 2011; Scherner et al. 2013; Gianni et al. 2017). As a result, these marine forests are replaced by simple and less productive communities dominated by opportunistic taxa, such as turfs or barrens, in many areas worldwide (Vergés et al. 2014; Valdazo et al. 2017; Verdura et al. 2018).

A noticeable regression of marine forests has been described along some temperate and subtropical rocky shores, including the Mediterranean Sea and the Canary Islands (Thibaut et al. 2005; Bonaviri et al. 2011; Valdazo et al. 2017; Verdura et al. 2018). The archipelagos of the Azores, Madeira, Canary Islands and Cabo Verde are distributed along a latitudinal gradient in the Atlantic Ocean, with differences in climate and water temperature (Freitas et al. 2019). Nevertheless, all of them have recently experienced significant alterations in their coastal ecosystems and macroalgae formations (Sangil et al. 2018). In the last few decades, a severe decline in the populations of Gongolaria abies-marina (S.G.Gmelin) C.Agardh 1820 has been extensively documented in Gran Canaria Island (Valdazo et al. 2017).

Although previous studies have mentioned a possible decline in the populations of the family Sargassaceae in Madeira (Bianchi et al. 1998; Sangil et al. 2018), none has examined the magnitude and scale of this loss, probably due to the lack of data for these populations in the past. To properly document this collapse, we compile the available historical knowledge reporting the regression of macroalgal populations from intertidal and subtidal coastal areas of Madeira.

\section{From marine forests to collapse: the case of Madeira}

The island of Madeira $\left(32.7^{\circ} \mathrm{N},-17^{\circ} \mathrm{E}\right)$, which together with Porto Santo and the uninhabited islands of Desertas forms the Madeira Archipelago, has a mainly rocky coastline (Alves et al. 2001), made up of platforms and boulders. Sea surface-water temperatures usually range between 17.0 and $23.5^{\circ} \mathrm{C}$ (Abreu and Biscoito 1998; Schäfer et al. 2019). Our study concentrates on the strongly human-influenced southeast coast of the island, from Calheta to Baia d'Abra, covering a shoreline of approximately $70 \mathrm{~km}$. The southeast shore of Madeira has been the most studied part of the island over decades due to higher accessibility and better oceanic conditions throughout the year.

Before and during the 1980s, the south coast of Madeira was characterized by large habitat-forming species, mainly Cystoseira spp., Gongolaria spp., Ericaria spp., and Sargassum spp. (Levring et al., 1974; Canning-Clode, Wirtz, Kaufmann pers. obs; Bianchi et al. 1998). The brown algae Gongolaria abies-marina was the dominant algal species on the rocky coasts, generally distributed from the infralittoral to the upper circalittoral zone (Levring 1974; Augier 1985; Wildpret et al. 1987; Bianchi et al. 1998; Tuya and Haroun 2006). Other relevant species such as Ericaria selaginoides (Linnaeus) Molinari \& Guiry 2020, Cystoseira humilis Schousboe, Cystoseira foeniculacea (Linnaeus) Greville 1830, Sargassum vulgare C.Agardh, and Sargassum filipendula C.Agardh were also abundant in shallow rocky sublittoral and intertidal exposed areas decades ago (Levring 1974; Augier 1985; Bianchi et al. 1998). Most of the species mentioned above were present in great abundance in Funchal, Garajau, Reis Magos, Machico, and Caniçal, highlighting G. abies-marina as the dominant species (Table 1). Especially in Funchal, the most studied location, from 1974 to 1998, E. selaginoides, G. abies-marina, S. vulgare, and $S$. filipendula were dominant species. The same appears to be true for less studied locations in the past: photographs from the 1990s (Fig. 1) show the presence of marine forests at the south coast of Madeira, at least from Baia d'Abra (Fig. 1A) to Calheta (Fig. 1E), passing through other sites such as Machico (Fig. 1B), Santa Cruz (Fig. 1C), and Reis Magos (Fig. 1D). In later studies (2008-2009), our target species were classified as occasional, rare, or even absent (Freitas Ferreira 2011; Alves et al. 2019). A more recent study evaluating the coast of Madeira almost completely (Friedlander et al. 2017) indicates that canopy-forming species are absent on the southeast coast. In those few areas where they were still present, their coverage never exceeded $15 \%$. The bottoms were dominated by coralline crustose algae (CCA) and turfs up to $20 \mathrm{~m}$ depth (Friedlander et al. 2017). Sangil et al. (2018) found only Sargassum vulgare, in an extremely low coverage in the island $(0.002 \pm 0.002 \%)$; the other species of the family were absent. In a recent habitat mapping study of the Cabo Girão natural marine park, located on the south coast of Madeira, marine forests were not reported and species of the family Sargassaceae were totally absent from the species list for the area (Ribeiro and Neves 2020). Nowadays, benthic rocky bottoms are dominated by CCA or turfs and barrens, generally with a layer of sediment covering the benthos (Fig. 1). Currently, species of the family Sargassaceae are rare to find at the southeastern coast and seem to be restricted to intertidal 
Table 1 Presence/absence of different species of Sargassaceae family from 1974 to the present in different localities on the southeast coast of Madeira (from Calheta to Baia d'Abra). The presence has been quantified in 4 levels according to the descriptions of the consulted sources: dominant, abundant, occasional, present, and absent

\begin{tabular}{|c|c|c|c|c|c|c|c|c|c|c|}
\hline \multirow[t]{2}{*}{ Year } & \multirow[t]{2}{*}{ Taxa } & \multicolumn{8}{|c|}{$\mathrm{SW} \diamond \mathrm{SE}$} & \multirow[b]{2}{*}{ Baia' dAbra } \\
\hline & & Calheta & Ribeira Brava & Funchal & Garajau & Reis Magos & Santa Cruz & Machico & Caniçal & \\
\hline \multirow[t]{6}{*}{1974} & Levring, 1974 & & & & & & & & & \\
\hline & C. humilis & & & - & & - & & & & \\
\hline & C. foeniculacea & & & $\bullet$ & & & & & & \\
\hline & E. selaginoides & & & - & & & & & & \\
\hline & G. abies-marina & & & $\bullet \bullet \bullet$ & & $\bullet \bullet \bullet$ & & $\bullet \bullet \bullet$ & $\bullet \bullet \bullet$ & \\
\hline & S. vulgare & & & $\bullet \bullet$ & $\bullet \bullet$ & $\bullet$ & & & $\bullet \bullet$ & \\
\hline \multirow[t]{5}{*}{1985} & Augier, 1985 & & & & & & & & & \\
\hline & C. humilis & & & $\bullet$ & & & & & & \\
\hline & E. selaginoides & & & $\bullet \bullet \bullet$ & & & & & & \\
\hline & G. abies-marina & & & $\bullet \bullet \bullet$ & & & & & & \\
\hline & S. vulgare & & & $\bullet \bullet$ & & & & & & \\
\hline \multirow[t]{3}{*}{1991} & Reed \& Serrão (Per. Obs.) & & & & & & & & & \\
\hline & G. abies-marina & & & & & & & & & $\bullet \bullet$ \\
\hline & Sargassum sp. & & & & & & & & & $\bullet \bullet$ \\
\hline \multirow[t]{4}{*}{1995} & Wirtz (Per. Obs.) & & & & & & & & & \\
\hline & C. humilis & & & & & & $\bullet \bullet$ & & & \\
\hline & G. abies-marina & & & $\bullet \bullet$ & & $\bullet \bullet$ & & & & \\
\hline & S. filipendula & $\bullet \bullet$ & & & & & & $\bullet \bullet$ & & \\
\hline \multirow[t]{3}{*}{1998} & Bianchi, 1998 & & & & & & & & & \\
\hline & G. abies-marina & & & $\bullet \bullet \bullet$ & & & & & & \\
\hline & S. filipendula & & & $\bullet \bullet \bullet$ & & & & & & \\
\hline \multirow[t]{5}{*}{2000} & Haroun et al., 2003 & & & & & & & & & \\
\hline & C. humilis & & & & & - & & & & \\
\hline & C. foeniculacea & & & & & - & & & & \\
\hline & G. abies-marina & & & & & - & & & & \\
\hline & S. filipendula & & & & & - & & & & \\
\hline \multirow[t]{2}{*}{2007} & Canning-Clode (Per. Obs.) & & & & & & & & & \\
\hline & G. abies-marina & & & & & & & & - & \\
\hline \multirow[t]{5}{*}{2008} & Alves et al., 2019 & & & & & & & & & \\
\hline & Cystoseira sp. & & & $\circ$ & $\circ$ & $\circ$ & & $\circ$ & & \\
\hline & E. selaginoides & & & $\circ$ & $\circ$ & $\circ$ & & $\circ$ & & \\
\hline & G. abies-marina & & & $\circ$ & $\circ$ & $\circ$ & & $\circ$ & & \\
\hline & Sargassum sp. & & & $\bullet$ & $\circ$ & $\circ$ & & $\circ$ & & \\
\hline \multirow[t]{5}{*}{2009} & Ferreira, 2009 & & & & & & & & & \\
\hline & $\begin{array}{l}\text { Cystoseira } \mathrm{sp} . \\
\text { E. selaginoides }\end{array}$ & & $\bullet$ & $\bullet$ & & $\bullet$ & & & & \\
\hline & G. abies-marina & & $\bullet$ & - & & & & & & \\
\hline & Sargassum sp. & & & & & & & & & \\
\hline & S. filipendula & & & & & $\bullet \bullet$ & & & & \\
\hline \multirow[t]{4}{*}{2016} & Friedlander et al., 2017 & & & & & & & & & \\
\hline & G. abies-marina & $\circ$ & $\circ$ & $\circ$ & $\circ$ & $\circ$ & $\circ$ & $\circ$ & $\circ$ & $\circ$ \\
\hline & Sargassum sp. & $\circ$ & $\circ$ & - & $\circ$ & - & - & $\circ$ & - & $\circ$ \\
\hline & Sargassum vulgare & $\circ$ & $\circ$ & - & $\circ$ & $\circ$ & $\circ$ & $\circ$ & $\circ$ & $\circ$ \\
\hline \multirow[t]{6}{*}{2020} & Bernal-Ibáñez (Per. Obs.) & & & & & & & & & \\
\hline & C. humilis & $\circ$ & & - & - & - & & - & $\circ$ & - \\
\hline & C. foeniculacea & $\circ$ & & - & - & - & & - & - & $\circ$ \\
\hline & E. selaginoides & $\circ$ & & $\circ$ & $\circ$ & $\circ$ & & $\circ$ & $\circ$ & $\circ$ \\
\hline & G. abies-marina & $\circ$ & & - & $\circ$ & $\circ$ & & $\circ$ & $\circ$ & $\circ$ \\
\hline & Sargassum sp. & $\circ$ & & - & - & $\circ$ & & - & $\circ$ & $\circ$ \\
\hline \multirow[t]{6}{*}{2021} & Bernal-Ibáñez et al. (in prep.) & & & & & & & & & \\
\hline & C. humilis & $\circ$ & $\circ$ & - & - & $\circ$ & $\circ$ & - & $\circ$ & - \\
\hline & C. foeniculacea & $\circ$ & $\circ$ & - & - & - & $\circ$ & - & - & $\circ$ \\
\hline & E. selaginoides & $\circ$ & $\circ$ & $\circ$ & $\circ$ & $\circ$ & $\circ$ & $\circ$ & $\circ$ & $\circ$ \\
\hline & G. abies-marina & $\circ$ & $\circ$ & $\circ$ & $\circ$ & $\circ$ & $\circ$ & $\circ$ & $\circ$ & $\circ$ \\
\hline & Sargassum sp. & $\circ$ & $\circ$ & - & - & - & $\circ$ & $\circ$ & $\circ$ & $\circ$ \\
\hline
\end{tabular}




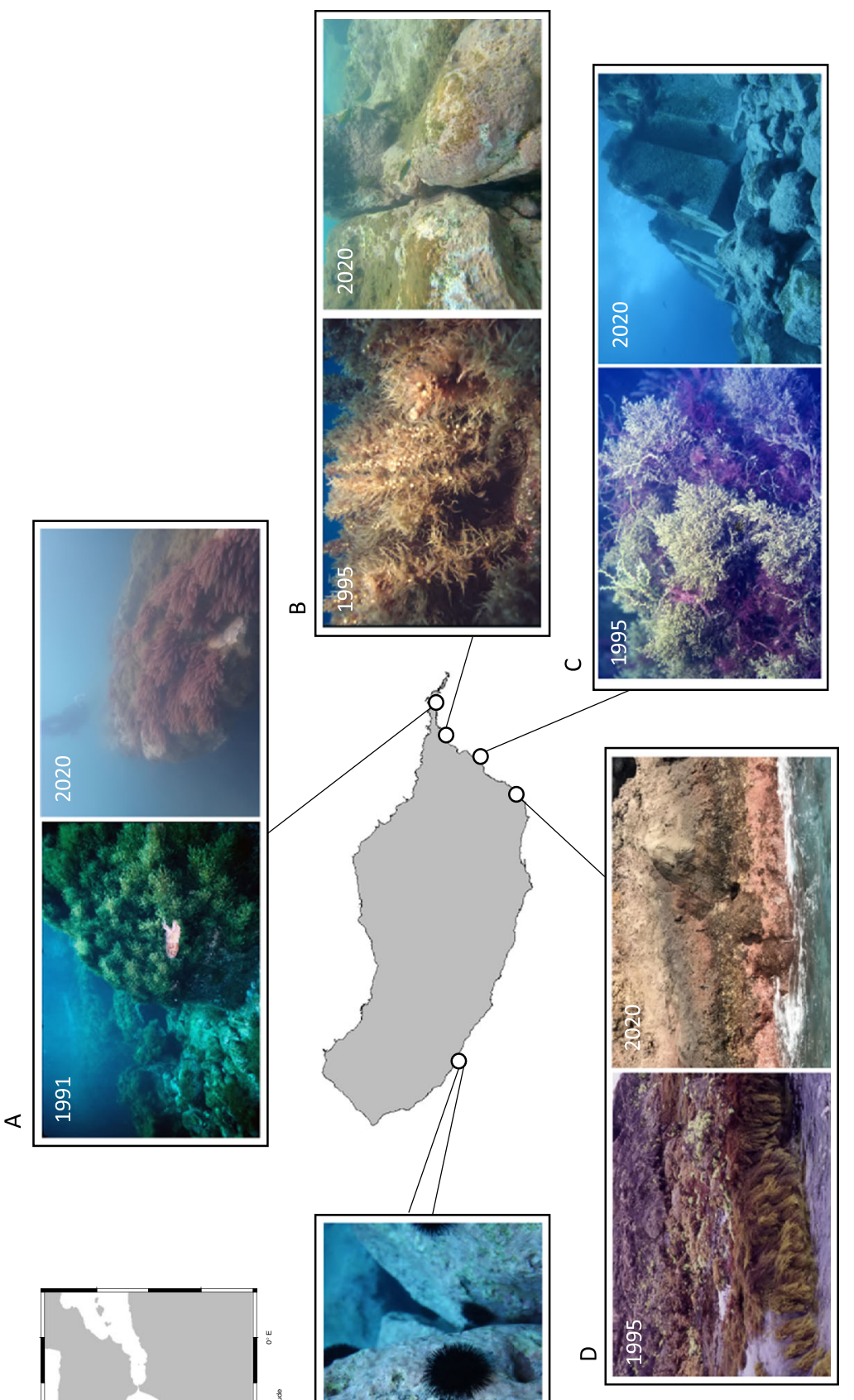

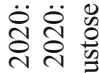

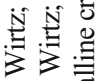

a a

흐은

는

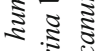

$\cup$

\%ั.

ะ ัิ

ㄱ ن ठิ

चू

究

U 总

ํㅣㄹ

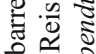

元

तें क्षे

ثै ڤे

ह

용

ลิ

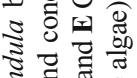

空范

的苛苟

च

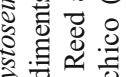

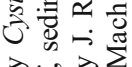

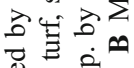

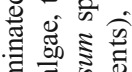

वे न

औ

䒕

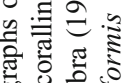

क⿺辶一兀

글

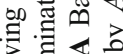

के

क 조워

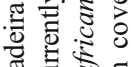

एँ

녕 명ㅇㅇ

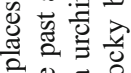

용

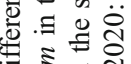

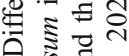

-

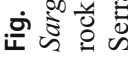


rockpools in specific locations. The only macroalgae found covering larger areas nowadays are Asparagopsis taxiformis (Delile) Trevisan, Padina pavonica (Linnaeus) Thivy, and other Dictyotales (Friedlander et al. 2017; Sangil et al. 2018).

Marine forests in Madeira have gone from dominating large rocky areas to being replaced by a simple and less productive system with a high presence of CCA and filamentous algae (Friedlander et al. 2017; Sangil et al. 2018). Everything seems to indicate that this phase change began in the first decade of the 2000 s, at least in the vicinity of Funchal bay, a date very similar to that provided by similar studies in the Canary Islands (Valdazo et al. 2017). This is most evident at Funchal (the area most studied), where Sargassaceae species went from being dominant to rare in less than 10 years (Table 1). Other places along the SE coast of Madeira seem to follow the same pattern. Despite the lack of time-series data for these populations in Madeira, the scenario appears to be very similar to the one in the Canary Islands, where G. abies-marina populations declined 99\% (Valdazo et al. 2017).

\section{Possible causes and impacts}

Changes in the distribution and extension of Sargassaceae species in Madeira in the last decades are evident and dramatic. Very few algal species in the world have been adequately evaluated over decades due to a lack of historical data (Blanfuné et al. 2016). Madeira is no exception; its remoteness, oceanic conditions, and cliff-lined coast have been a challenge for the development of phycological studies in the past. Despite the limitations of our study due to the lack of time series, our results are in agreement with studies published in the Canary Islands (Hernández et al. 2008a; Valdazo et al. 2017), in the Mediterranean Sea (Thibaut et al. 2005; Mangialajo et al. 2008; Thibaut et al. 2015), and in general for canopy-forming brown macroalgae around the world (Wahl et al. 2015). The area occupied by these species in the past could be underestimated due to the lack of techniques and procedures evaluating these communities over the years, including populations below $20 \mathrm{~m}$ depth. Despite this, we can assume these inaccuracies since the regression is evident, especially in the intertidal and shallow subtidal zones. This decline is a general pattern on the southeast coast of Madeira, regardless of levels of anthropogenic pressure or protection, because even in those protected areas (such as Garajau), it has been dramatic.

The decline of these species seems to have occurred in a period of greater urbanization and tourism development and, therefore, many local impacts, as has happened in the Canary Islands (Tuya et al. 2014; Ferrer-Valero et al. 2017). In recent decades, several human pressures, particularly coastal development on the shoreline of Madeira, have increased considerably, especially on the more heavily inhabited and accessible southeast coast. The numerous constructions that have taken place in recent decades (e.g., hotels, artificial pools, ports, marinas, private houses, and roads) are human activities with a clear impact on the coastal environment. These constructions are especially important in the Bay of Funchal, where the coastline has been intensively modified. Popular knowledge recognized that debris generated from the construction of new coastal infrastructure created a layer of mud on the bottom, impacting the habitats (Martínez-Escauriaza et al. 2020a). Intensive urbanization causes substantial seaweed species declines, particularly among Phaeophyceae, associated with habitat destruction and the degradation of water quality (Scherner et al. 2013; Cacabelos et al. 2016). After a monitoring program to assess the impact of urban wastewater discharges through submarine outfalls and to explain the processes that determine water quality in the south coast of Madeira Island, Campuzano et al. (2010) concluded that nutrient dynamics were mainly related to mesoscale events and land-based inputs are unlikely to play a strong role in the ecological processes of the region. The disappearance or modification of continuous coastal shores (or natural rocky platforms) can disable the normal development of macroalgal species and reduce the habitat available for recruitment and settlement (Steneck et al. 2020; Perkol-Finkel and Airoldi 2010; Blanfuné et al. 2016; Cacabelos et al. 2016; Ferrario et al. 2016). This can even have consequences at the genetic level. For example, the genus Cystoseira, Ericaria, and Gongolaria are species with low dispersion, and reproductive drifting thalli in floating rafts is the main mechanism of connectivity between populations (Susini et al. 2007). If connectivity is restricted, isolated small populations with poor gene pools are more vulnerable to possible impacts (Buonomo et al. 2017). In addition, modifications of the coastline can lead to changes in the light and turbidity regimes due to changes in hydrodynamics (Tuya et al. 2002). These stressors have been impacting the seagrass Cymodocea nodosa that has almost disappeared along the southern coast of Madeira, where it was already extremely reduced by coastal construction impact before 2007 (Cunha et al. 2013; Kaufmann and Maranhão 2017; Schäfer et al. 2020).

Another detrimental impact on canopy-forming algae may be a large amount of sediment loads from land after intense rainfalls, also affecting light availability and turbidity regimes. The mean annual precipitation varies between 600 and $800 \mathrm{~mm}$ on the south coast versus $1500-2000 \mathrm{~mm}$ on the north, reaching $3000 \mathrm{~mm}$ on top eastern mountains (Baioni et al. 2011) but sometimes leading to severe torrential rains, as occurred in February 2010 when rainfall attained $500 \mathrm{~mm}$ in a single day (Fragoso et al. 2012). The increase in floods is directly related to human activity on the south coast of Madeira (Baioni et al. 2011). Due to the loss of forest mass 
on the island, as a consequence of urbanization and agriculture (Baioni et al. 2011; Fernández-Palacios et al. 2016), the retention of sediments has been greatly diminished, increasing river sediment loads that reach the coast in greater quantities (Baioni et al. 2011; Quartau et al. 2018). During these events, the water turns brownish with high turbidity, contrasting with the typical crystalline waters of the island, and this can negatively affect photosynthetic organisms (Bernal-Ibáñez per. obs.; Kaufmann and Maranhão 2017). Moreover, these sediments end up deposited on the sea bed, which represents a mechanical impact for all sessile species and prevents the settlement of algae propagules (Schiel and Gunn 2019). The negative impact of turbidity and sedimentation on macroalgae has already been studied in other locations (Airoldi and Cinelli 1997; Airoldi 2003). Further research is necessary to evaluate the impact of turbidity and sediment deposition on the response of benthic communities in Madeira, as not only photosynthetic organisms can be affected (Kjelland et al. 2015).

In Madeira, barrens are dominated by the sea urchin, Diadema africanum Rodríguez, Hernández, Clemente \& Coppard, 2013, cited as the main driver of the variability in the shallow benthic communities (Hernández et al. 2008b), reaching densities of up to $6 \pm 4.8$ individuals $/ \mathrm{m}^{2}$ in the southeast coast (Alves et al. 2001, 2019; Gizzi et al. 2020). Overfishing is one of the main reasons underlying the displacement of large macroalgal formations by sea urchin barrens (Guidetti et al. 2005; Sangil et al. 2011). The intense coastal fishing activity promotes the capture of top predators in the systems, which can be direct predators of settling stages and juveniles of sea urchins. Subsequently, sea urchin populations flourish as more individuals are recruited, and they reach larger sizes. The high recreative fishing activity on the coast of Madeira has been studied (Martínez-Escauriaza et al. 2020a, 2020b) in addition to the effect of the predation of D. africanum on macroalgae (Alves et al. 2003). Other grazers, such as the sea urchins Arbacia lixula and herbivorous fishes (Sparisoma cretense and Sarpa salpa), also contribute to the consumption of Sargassaceae species (Verges et al. 2009).

In the current context of climate change, ocean warming implies a global impact on coastal benthic communities and especially on marine forests (Wernberg et al. 2013; FilbeeDexter et al. 2020; Smale 2020), producing the decline of fucoids and their displacement to cold waters (Wernberg et al. 2011). Regional studies have shown the negative effect of warming on brown macroalgae (Sansón et al. 2013). In addition to rising temperatures, the role of extreme hightemperature events (marine heatwaves) also has a negative impact on fucoid populations (Vergés et al. 2014; ArafehDalmau et al. 2020). As the magnitude and frequency of extreme events are expected to increase under climate change (Gaines and Denny 1993; Coumou and Rahmstorf 2012; Frölicher and Laufkötter 2018), this should be taken into consideration in future experiments testing their effects on canopy-forming algae in Madeira.

The degradation of the marine forests in Madeira appears to be the result of a set of drivers interacting across regional and local scales that have increased in frequency and magnitude in recent decades: increase of overgrazing (especially D. africanum) as a consequence of imbalanced food chains by overfishing, increase of turbidity and sedimentation, habitat loss and fragmentation, climate change effects, among others. All this has led to a considerable recession of the populations of family Sargassaceae, making them taxa that are very difficult to find nowadays. This ecological loss brings with it the invaluable loss of numerous associated species, as well as all the ecosystem services provided by these macroalgae, from which society benefits both directly and indirectly (Ballesteros et al. 1998; Boudouresque 2004; Buonomo et al. 2018). Marine forests represent a vital habitat for nesting, establishment, and development of numerous associated species (some of them of economic interest) threatened with the regression of their habitat. The associated loss of biodiversity is likely to have a negative effect on the ecosystem services produced by marine forests in Madeira.

It is time to assess and understand all the ecological mechanisms and processes involved in this recession, taking into account the different interacting human pressures and the resistance of remnant populations. More efforts should be made to protect Madeira's coastal systems, following successful examples from the region such as the MPA in La Palma Island (Sangil et al. 2012) or Selvagens Islands (Friedlander et al. 2017). These cases show the important effect of active protection over benthic beds, presenting well-preserved macroalgal communities and even recovering communities lost in the past in less than 4 years (Sangil et al. 2012).

This study highlights the need to monitor the remaining populations of the species belonging to the family Sargassaceae in Madeira. Their decline appears to be a general pattern in the Macaronesian region, especially in Madeira and the Canary Islands. It is obviously necessary to collect more data to monitor this decline and to evaluate the state of these populations in the coming years. The information provided in this study is a basis to evaluate the conservation of the family Sargassaceae on the island of Madeira.

Funding $\mathrm{AB}, \mathrm{EC}$, and IG were financially supported by pre- and postdoctoral grants in the framework of the 2015 ARDITI Grant Programme Madeira 14-20 (Project M1420-09-5369-FSE-000002). JCC is funded by national funds through FCT - Fundação para a Ciência e a Tecnologia, I.P., under the Scientific Employment Stimulus - Institutional Call [CEECINST/00098/2018]. Activities within this study were partially supported by projects PLASMAR+ (MAC2/1.1a/347) and MIMAR+ (MAC2/4.6d/249) in the framework of the INTERREG MAC 20142020 Programme. This study was supported by Fundação para a Ciência e Tecnologia (FCT) through the strategic project UIDB/04292/ 2020 granted to MARE, as well as by project SeaForest Portugal, grant 
Fundo Azul, FA_06_2017_067 to CCMAR and UMa. This is contribution 73 from the Smithsonian's MarineGEO and Tennenbaum Marine Observatories Network.

Open Access This article is licensed under a Creative Commons Attribution 4.0 International License, which permits use, sharing, adaptation, distribution and reproduction in any medium or format, as long as you give appropriate credit to the original author(s) and the source, provide a link to the Creative Commons licence, and indicate if changes were made. The images or other third party material in this article are included in the article's Creative Commons licence, unless indicated otherwise in a credit line to the material. If material is not included in the article's Creative Commons licence and your intended use is not permitted by statutory regulation or exceeds the permitted use, you will need to obtain permission directly from the copyright holder. To view a copy of this licence, visit http://creativecommons.org/licenses/by/4.0/.

\section{References}

Abreu AD, Biscoito MJ (1998) A vida nos mares da Madeira. Islenha 23: $5-14$

Airoldi L, Cinelli F (1997) Effects of sedimentation on subtidal macroalgal assemblages: an experimental study from a Mediterranean rocky shore. J Exp Mar Biol Ecol 215:269-288. https://doi.org/10.1016/S0022-0981(96)02770-0

Airoldi L (2003) The effects of sedimentation on rocky coast assemblages. Oceanogr Mar Biol Annu Rev 41:161-236

Alves F, Chícharo LM, Serrão E, Abreu AD (2001) Algal cover and sea urchin spatial distribution at Madeira Island (NE Atlantic). Sci Mar 65:383-392. https://doi.org/10.3989/scimar.2001.65n4383

Alves F, Chícharo LM, Serrão E, Abreu AD (2003) Grazing by Diadema antillarum (Philippi) upon algal communities on rocky substrates. Sci Mar 67:307-311. https://doi.org/10.3989/scimar.2003.67n3307

Alves F, Canning-Clode J, Ribeiro C, Gestoso I, Kaufmann M (2019) Local benthic assemblages in shallow rocky reefs find refuge in a marine protected area at Madeira Island. J Coast Conserv 23:373383. https://doi.org/10.1007/s11852-018-0669-y

Arafeh-Dalmau N, Schoeman DS, Montaño-Moctezuma G, Micheli F, Rogers-Bennett L, Olguin-Jacobson C, Possingham HP (2020) Marine heat waves threaten kelp forests. Science 367:635-635. doi: https://doi.org/10.1126/science.aba5244

Augier H (1985) Premiére contribution a l'étude et a la cartographie des biocenoses marines benthiques de l'île de Madere. Bol Mus Mun Funchal 37(168):86-129

Baioni D, Castaldini D, Cencetti C (2011) Human activity and damaging landslides and floods on Madeira Island. Nat Hazards Earth Syst Sci 11:3035-3046. https://doi.org/10.5194/nhess-11-3035-2011

Ballesteros E (1992) Els vegetals i la zonació litoral: espècies, comunitats i factors que influeixen en la seva distribució. Institut d'Estudis Catalans.

Ballesteros E, Sala E, Garrabou J, Zabala M (1998) Community structure and frond size distribution of a deep water stand of Cystoseira spinosa (Phaeophyta) in the Northwestern Mediterranean. Eur J Phycol 33:121-128. https://doi.org/10.1017/S0967026298001541

Bermejo R, Chefaoui RM, Engelen AH, Buonomo R, Neiva J et al (2018) Marine forests of the Mediterranean-Atlantic Cystoseira tamariscifolia complex show a southern Iberian genetic hotspot and no reproductive isolation in parapatry. Sci Rep 8(1):1-13. https://doi.org/10.1038/s41598-018-28811-1

Bianchi CN, Morri C, Sartoni G, Wirtz P (1998) Sublittoral epibenthic communities around Funchal (Island of Madeira, NE Atlantic): update of previous information and comparison with the Mediterranean Sea. Bol Mus Mun Fun 5:59-80 ISSN 0870-3876
Blanfuné A, Boudouresque CF, Verlaque M, Thibaut T (2016) The fate of Cystoseira crinita, a forest-forming Fucale (Phaeophyceae, Stramenopiles), in France (North Western Mediterranean Sea). Estuar Coast Shelf Sci 181:196-208. https://doi.org/10.1016/j.ecss. 2016.08.049

Bonaviri C, Vega Fernández T, Fanelli G, Badalamenti F, Gianguzza P (2011) Leading role of the sea urchin Arbacia lixula in maintaining the barren state in southwestern Mediterranean. Mar Biol 158:25052513. https://doi.org/10.1007/s00227-011-1751-2

Boudouresque CF (2004) Marine biodiversity in the Mediterranean: status of species, populations and communities. Travaux scientifiques du Parc national de Port-Cros 20:97-146

Buonomo R, Assis J, Fernandes F et al (2017) Habitat continuity and stepping-stone oceanographic distances explain population genetic connectivity of the brown alga Cystoseira amentacea. Mol Ecol 26: 766-780. https://doi.org/10.1111/mec. 13960

Buonomo R, Chefaoui RM, Lacida RB, Engelen AH, Serrão EA, Airoldi L (2018) Predicted extinction of unique genetic diversity in marine forests of Cystoseira spp. Mar Environ Res 138:119-128. https:// doi.org/10.1016/j.marenvres.2018.04.013

Cacabelos E, Martins GM, Thompson R, Prestes AC, Azevedo JMN et al (2016) Factors limiting the establishment of canopy-forming algae on artificial structures. Estuar Coast Shelf Sci 181:277-283. https:// doi.org/10.1016/j.ecss.2016.08.036

Campuzano F, Nunes S, Malhadas M, Neves, R (2010) Modelling hydrodynamics and water quality of Madeira Island (Portugal). GLOBEC International Newsletter, 40-42.

Clemente S (2007) Evolución de las poblaciones del erizo Diadema aff. antillarum en Canarias y valoración de la depredación como factor de control. Dissertation, Universidad de La Laguna, Tenerife.

Coumou D, Rahmstorf S (2012) A decade of weather extremes. Nat Clim Chang 2:491-496. https://doi.org/10.1038/nclimate1452

Cunha AH, Assis JF, Serrão E (2013) Seagrasses in Portugal: a most endangered marine habitat. Aquat Bot 104:193-203. https://doi. org/10.1016/j.aquabot.2011.08.007

Dayton PK (1985) Ecology of kelp communities. Annu Rev Ecol Syst 16: 215-245. https://doi.org/10.1146/annurev.es.16.110185.001243

Fernández-Palacios JM, Nogué S, Criado C, Connor S, Góis-Marques C et al (2016) Climate change and human impact in Macaronesia. Pag Mag 24:68-69. https://doi.org/10.22498/pages.24.2.68

Ferrario F, Iveša L, Jaklin A, Perkol-Finkel S, Airoldi L (2016) The overlooked role of biotic factors in controlling the ecological performance of artificial marine habitats. J Appl Ecol 53(1):16-24. https:// doi.org/10.1111/1365-2664.12533

Ferrer-Valero N, Hernández-Calvento L, Hernández-Cordero AI (2017) Human impacts quantification on the coastal landforms of Gran Canaria Island (Canary Islands). Geormorphology 286:58-67. https://doi.org/10.1016/j.geomorph.2017.02.028

Filbee-Dexter K, Wernberg T, Grace S, Thormar J, Fredriksen S et al (2020) Marine heatwaves and the collapse of marginal North Atlantic kelp forests. Sci Rep 10:1-11. https://doi.org/10.1038/ s41598-020-70273-x

Fragoso M, Trigo RM, Pinto JG, Lopes S, Lopes A et al (2012) The 20 February 2010 Madeira flash-floods: synoptic analysis and extreme rainfall assessment. Nat Hazards Earth Syst Sci 12:715-730. https:// doi.org/10.5194/nhess-12-715-2012

Franco JN, Wernberg T, Bertocci I, Duarte P, Jacinto D et al (2015) Herbivory drives kelp recruits into 'hiding' in a warm ocean climate. Mar Ecol Prog Ser 536:1-9. https://doi.org/10.3354/meps11445

Fraschetti S, Guarnieri G, Bevilacqua S, Terlizzi A, Claudet J et al (2011) Conservation of Mediterranean habitats and biodiversity countdowns: what information do we really need? Aquat Conserv Mar Freshwat Ecosyst 21:299-306. https://doi.org/10.1002/aqc.1185

Freitas Ferreira SJ (2011) Contributo para o estudo das macroalgas do intertidal da ilha da Madeira. Diversidade, distribução e 
sazonalidade. Dissertação da mestrado, Universidade da Madeira, Portugal, $112 \mathrm{pp}$

Freitas R, Romeiras M, Silva L, Cordeiro R, Madeira P et al (2019) Restructuring of the 'Macaronesia' biogeographic unit: a marine multi-taxon biogeographical approach. Sci Rep 9(1):1-18. https:// doi.org/10.1038/s41598-019-51786-6

Friedlander AM, Ballesteros E, Clemente S, Gonçalves EJ, Estep A et al (2017) Contrasts in the marine ecosystem of two Macaronesian islands: a comparison between the remote Selvagens Reserve and Madeira Island. PLoS One 12:e187935. https://doi.org/10.1371/ journal.pone.0187935

Frölicher TL, Laufkötter C (2018) Emerging risks from marine heat waves. Nat Commun 9:650. https://doi.org/10.1038/s41467-01803163-6

Gaines SD, Denny MW (1993) The largest, smallest, highest, lowest, longest, and shortest: extremes in ecology. Ecology 74:16771692. https://doi.org/10.2307/1939926

Giakoumi S, Cebrian E, Kokkoris GD, Ballesteros E, Sala E (2012) Relationships between fish, sea urchins and macroalgae: the structure of shallow rocky sublittoral communities in the Cyclades, Eastern Mediterranean. Estuar Coast Shelf Sci 109:1-10. https:// doi.org/10.1016/j.ecss.2011.06.004

Gianni F, Bartolini F, Pey A, Laurent M, Martins GM et al (2017) Threats to large brown algal forests in temperate seas: the overlooked role of native herbivorous fish. Sci Rep 7:1-13. https://doi.org/10.1038/ s41598-017-06394-7

Gizzi F, Jiménez J, Schäfer S, Castro N, Costa S et al (2020) Before and after a disease outbreak: tracking a keystone species recovery from a mass mortality event. Mar Environ Res 156:104905. https://doi.org/ 10.1016/j.marenvres.2020.104905

Gros C (1978) Le genre Cystoseira sur la côte des Albères. Répartition, écologie, morphogenèse. Dissertation, Université Pierre et Marie Curie.

Guidetti P, Bussotti S, Boero F (2005) Evaluating the effects of protection on fish predators and sea urchins in shallow artificial rocky habitats: a case study in the northern Adriatic Sea. Mar Environ Res 59(4): 333-348. https://doi.org/10.1016/j.marenvres.2004.05.008

Hernández JC, Clemente S, Sangil C, Brito A (2008a) Actual status of the sea urchin Diadema aff. antillarum populations and macroalgal cover in marine protected areas compared to a highly fished area (Canary Islands - Eastern Atlantic Ocean). Aquat Conserv Mar Freshwat Ecosyst 18(7):1091-1108. https://doi.org/10.1002/aqc. 903

Hernández JC, Clemente S, Sangil C, Brito A (2008b) The key role of the sea urchin Diadema aff. antillarum in controlling macroalgal assemblages throughout the Canary Islands (eastern subtropical Atlantic): a spatio-temporal approach. Mar Environ Res 66(2):259-270. https://doi.org/10.1016/j.marenvres.2008.03.002

Hill NA, Blount C, Poore AG, Worthington D, Steinberg PD (2003) Grazing effects of the sea urchin Centrostephanus rodgersii in two contrasting rocky reef habitats: effects of urchin density and its implications for the fishery. Mar Freshw Res 54:691-700. https://doi. org/10.1071/MF03052

Hirsh HK, Nickols KJ, Takeshita Y, Traiger SB, Mucciarone DA et al (2020) Drivers of biogeochemical variability in a central California kelp forest: implications for local amelioration of ocean acidification. J Geophys Res Oceans 125. https://doi.org/10.1029/ 2020JC016320

Hoffmann L, Renard R, Demoulin V (1992) Phenology, growth and biomass of Cystoseira balearica in Calvi (Corsica). Mar Ecol Progress Series Oldendorf 80:249-254. https://doi.org/10.3354/ meps080249

Jones CG, Lawton JH, Shachak M (1997) Positive and negative effects of organisms as physical ecosystem engineers. Ecology 78:19461957. https://doi.org/10.1890/0012-9658(1997)078[1946: PANEOO]2.0.CO;2
Kaufmann M, Maranhão M (2017) Environmental monitoring of a seagrass bed at the south coast of Madeira Island. 3rd European Conference on Scientific Diving, Funchal. https://doi.org/10. 13140/RG.2.2.22729.75363

Kjelland ME, Woodley CM, Swannack TM, Smith DL (2015) A review of the potential effects of suspended sediment on fishes: potential dredging-related physiological, behavioral, and transgenerational implications. Environ Syst Decisions 35:334-350. https://doi.org/ 10.1007/s10669-015-9557-2

Levring T (1974) The marine algae of the Archipelago of Madeira. Bolm Mus Mun Funchal 28(125):5-111

Mangialajo L, Chiantore M, Cattaneo-Vietti R (2008) Loss of fucoid algae along a gradient of urbanisation and relationships with the structure of benthic assemblages. Mar Ecol Prog Ser 358:63-74. https://doi.org/10.3354/meps07400

Martínez-Escauriaza R, Hermida M, Villasante S, Gouveia L, Gouveia N et al (2020a) Importance of recreational shore angling in the archipelago of Madeira, Portugal (northeast Atlantic). Sci Mar. https:// doi.org/10.3989/scimar.05046.30A

Martínez-Escauriaza R, Vieira C, Gouveia L, Gouveia N, Hermida M (2020b) Characterization and evolution of spearfishing in Madeira archipelago, Eastern Atlantic. Aquat Living Resour 33:15. https:// doi.org/10.1051/alr/2020015

Panayotidis P, Feretopoulou J, Montesanto B (1999) Benthic vegetation as an ecological quality descriptor in an Eastern Mediterranean coastal area (Kalloni Bay, Aegean Sea, Greece). Estuar Coast Shelf Sci 48:205-214. https://doi.org/10.1006/ecss.1998.0411

Perkol-Finkel S, Airoldi L (2010) Loss and recovery potential of marine habitats: an experimental study of factors maintaining resilience in subtidal algal forests at the Adriatic Sea. PLoS One 5:e10791. https://doi.org/10.1371/journal.pone.0010791

Pinedo S, Garcia M, Satta MP, Torras X, Ballesteros E (2006) Littoral benthic communities as indicators of environmental quality in Mediterranean waters. Second Mediterranean Symposium on Marine Vegetation, pp.205- 210. UNEP - MAP - RAC/SPA, Athenas, Greece. Available: http://digital.csic.es/bitstream/10261/ 7667/1/ Binder1.pdf

Quartau R, Ramalho RS, Madeira J, Santos R, Rodrigues A et al (2018) Gravitational, erosional and depositional processes on volcanic ocean islands: insights from the submarine morphology of Madeira Archipelago. Earth Planet Sci Lett 482:288-299. https:// doi.org/10.1016/j.epsl.2017.11.003

Ribeiro C, Neves P (2020) Habitat mapping of Cabo Girão Marine Park (Madeira island): a tool for conservation and management. J Coast Conserv 24:1-16. https://doi.org/10.1007/s11852-019-00724-9

Roleda MY, Dethleff D (2011) Storm-generated sediment deposition on rocky shores: Simulating burial effects on the physiology and morphology of Saccharina latissima sporophytes. Mar Biol Res 7:213223. https://doi.org/10.1080/17451000.2010.497189

Sangil C, Sansón M, Afonso-Carrillo J (2011) Spatial variation patterns of subtidal seaweed assemblages along a subtropical oceanic archipelago: thermal gradient vs herbivore pressure. Estuar Coast Shelf Sci 94(4):322-333. https://doi.org/10.1016/j.ecss.2011.07.004

Sangil C, Clemente S, Martín-García L, Hernández JC (2012) No-take areas as an effective tool to restore urchin barrens on subtropical rocky reefs. Estuar Coast Shelf Sci 112:207-215. https://doi.org/ 10.1016/j.ecss.2012.07.025

Sangil C, Martins GM, Hernández JC, Alves F, Neto AI et al (2018) Shallow subtidal macroalgae in the North-eastern Atlantic archipelagos (Macaronesian region): a spatial approach to community structure. Eur J Phycol 53:83-98. https://doi.org/10.1080/09670262. 2017.1385098

Sansón M, Sangil C, Orellana S et al (2013) Do the size shifts of marine macroalgae match the warming trends in the Canary Islands? XIX Simposio de Botanica Criptogamica, Las Palmas de Gran Canaria, pp 24-28 
Schäfer S, Monteiro J, Castro N, Rilov G, Canning-Clode J (2019) Cronius ruber (Lamarck, 1818) arrives to Madeira Island: a new indication of the ongoing tropicalization of the northeastern Atlantic. Mar Biodivers 49:2699-2707. https://doi.org/10.1007/ s12526-019-00999-Z

Schäfer S, Monteiro J, Castro N, Gizzi F, Henriques F et al (2020) Lost and found: a new hope for the seagrass Cymodocea nodosa in the marine ecosystem of a subtropical Atlantic Island. Reg Stud Mar Sci 41:101575. https://doi.org/10.1016/j.rsma.2020.101575

Scherner F, Horta PA, de Oliveira EC, Simonassi JC, Hall-Spencer JM et al (2013) Coastal urbanization leads to remarkable seaweed species loss and community shifts along the SW Atlantic. Mar Pollut Bull 76:106-115. https://doi.org/10.1016/j.marpolbul.2013.09.019

Schiel DR, Foster MS (2006) The population biology of large brown seaweeds: ecological consequences of multiphase life histories in dynamic coastal environments. Annu Rev Ecol Evol Syst 37:343372. https://doi.org/10.1146/annurev.ecolsys.37.091305.110251

Schiel DR, Gunn TD (2019) Effects of sediment on early life history stages of habitat-dominating fucoid algae. J Exp Mar Biol Ecol 516:44-50. https://doi.org/10.1016/j.jembe.2019.04.005

Smale DA, Burrows MT, Moore P, O'Connor N, Hawkins SJ (2013) Threats and knowledge gaps for ecosystem services provided by kelp forests: a northeast Atlantic perspective. Ecol Evol 3:40164038. https://doi.org/10.1002/ece3.774

Smale DA (2020) Impacts of ocean warming on kelp forest ecosystems. New Phytol 225:1447-1454. https://doi.org/10.1111/nph.16107

Soltan D, Verlaque M, Boudouresque CF, Francour P (2001) Changes in macroalgal communities in the vicinity of a Mediterranean sewage outfall after the setting up of a treatment plant. Mar Pollut Bull 42: 59-70. https://doi.org/10.1016/S0025-326X(00)00116-8

Steneck RS, Graham MH, Bourque BJ, Corbett D, Erlandson JM et al (2020) Kelp forest ecosystems: biodiversity, stability, resilience and future. Environ Conserv 29:436-459. https://doi.org/10.1017/ S0376892902000322

Susini ML, Thibaut T, Meinesz A et al (2007) A preliminary study of genetic diversity in Cystoseira amentacea (C. Agardh) Bory var. stricta Montagne (Fucales, Phaeophyceae) using random amplified polymorphic DNA. Phycologia 46:605-611. https://doi.org/10. 2216/06-100.1

Thibaut T, Pinedo S, Torras X, Ballesteros E (2005) Long-term decline of the populations of Fucales (Cystoseira spp. and Sargassum spp.) in the Albères coast (France, North-western Mediterranean). Mar Pollut Bull 50:1472-1489. https://doi.org/10.1016/j.marpolbul. 2005.06.014

Thibaut T, Blanfuné A, Boudouresque CF, Verlaque M (2015) Decline and local extinction of Fucales in French Riviera: the harbinger of future extinctions? Mediterr Mar Sci 16(1):206-224. https://doi.org/ $10.12681 / \mathrm{mms} .1032$

Tuya F, Martín JA, Luque A (2002) Impact of a marina construction on a seagrass bed at Lanzarote (Canary Islands). J Coast Conserv 8:157. https://doi.org/10.1652/1400-0350(2002)008[0157:IOAMCO]2.0. $\mathrm{CO} ; 2$
Tuya F, Boyra A, Sanchez-Jerez P, Barbera C, Haroun R (2004) Can one species determine the structure of the benthic community on a temperate rocky reef? The case of the long-spined sea-urchin Diadema antillarum (Echinodermata: Echinoidea) in the eastern Atlantic. Hydrobiologia 519:211-214. https://doi.org/10.1023/B:HYDR. 0000026599.57603.bf

Tuya F, Haroun RJ (2006) Spatial patterns and response to wave exposure of shallow water algal assemblages across the Canarian Archipelago: a multi-scaled approach. Mar Ecol Prog Ser 311:1528. https://doi.org/10.3354/meps311015

Tuya F, Ribeiro-Leite L, Arto-Cuesta N et al (2014) Decadal changes in the structure of Cymodocea nodosa seagrass meadows: natural vs. human influences. Estuar Coast Shelf Sci 137:41-49. https://doi. org/10.1016/j.ecss.2013.11.026

Valdazo J, Viera-Rodríguez MA, Espino F, Haroun R, Tuya F (2017) Massive decline of Cystoseira abies-marina forests in Gran Canaria Island (Canary Islands, eastern Atlantic). Sci Mar 81:499-507. https://doi.org/10.3989/scimar.04655.23A

Verdura J, Sales M, Ballesteros E, Cefalì ME, Cebrian E (2018) Restoration of a canopy-forming alga based on recruitment enhancement: methods and long-term success assessment. Front Plant Sci 9: 1832. https://doi.org/10.3389/fpls.2018.01832

Verges V, Alcoverro T, Ballesteros E (2009) Role of fish herbivory in structuring the vertical distribution of canopy algae Cystoseira spp. in the Mediterranean Sea. Mar Ecol Prog Ser 375:1-11. https://doi. org/10.3354/meps07778

Vergés A, Steinberg PD, Hay ME, Poore AG, Campbell AH et al (2014) The tropicalization of temperate marine ecosystems: climatemediated changes in herbivory and community phase shifts. Proc R Soc B Biol Sci 281:20140846. https://doi.org/10.1098/rspb.2014. 0846

Wahl M, Molis M, Hobday AJ et al (2015) The responses of brown macroalgae to environmental change from local to global scales: direct versus ecologically mediated effects. Perspect Phycol 2:1130. https://doi.org/10.1127/pip/2015/0019

Wernberg T, Russell BD, Thomsen MS, Gurgel CFD, Bradshaw CJ et al (2011) Seaweed communities in retreat from ocean warming. Curr Biol 21:1828-1832. https://doi.org/10.1016/j.cub.2011.09.028

Wernberg T, Smale DA, Tuya F, Thomsen MS, Langlois TJ et al (2013) An extreme climatic event alters marine ecosystem structure in a global biodiversity hotspot. Nat Clim Chang 3:78-82. https://doi. org/10.1038/nclimate1627

Wildpret W, Gil-Rodríguez M, Afonso-Carrillo J (1987) Cartografía de los campos de algas y praderas de fanerógamas marinas del piso infralitoral del Archipiélago Canario. Consejería de Agricultura y Pesca Santa Cruz de Tenerife.

Publisher's note Springer Nature remains neutral with regard to jurisdictional claims in published maps and institutional affiliations. 